\title{
ИЗУЧЕНИЕ ИСХОДНОГО МАТЕРИАЛА ДЛЯ ИСПОЛЬЗОВАНИЯ В СЕЛЕКЦИОННОМ ПРОЦЕССЕ ПО СОЗДАНИЮ НОВЫХ СОРТОВ ДЫНИ
}

\author{
STUDYING OF ORIGINAL MATERIAL FOR USE \\ IN THE SELECTION PROCESS FOR CREATING \\ NEW MELON VARIETIES
}

М.С. Корнилова,

Е.А. Варивода

Быковская бахчевая селекционная опытная станция филиал Федерального научного центра овощеводства

\author{
M.S. Kornilova, \\ E.A. Varivoda
}

Bykovskaya melon selection experimental station -

a branch of the Federal Scientific Center of Vegetable Growing
Работа Быковской бахчевой селекционной опытной станции включает в том числе выведение сортов дыни, не уступающих районированным сортам по хозяйственно ценным признакам, устойчивости к внешним факторам среды, вкусовым качествам. Межсортовая гибридизация с применением повторных, ступенчатых скрещиваний - главное направление подбора исходного материала в селекции дыни. Отбор и анализ исходного материала для скрещивания сортов с индивидуальной способностью передачи потомству ценных признаков является важной селекционной задачей. С целью расширения ассортимента адаптированных продуктивных сортов дыни выделенные в коллекционных питомниках образцы, решающие поставленную селекционную задачу, использованы для получения новых гибридных комбинаций дыни. В питомнике исходного материала изучено 8 перспективных гибридных комбинаций дыни, имеющих преимущество по ценным хозяйственным признакам перед лучшими районированными сортами. Установлено, что наиболее урожайными являются образцы: Дюна х Местный 625645 (Грузия), Гармония х Местный 626245 (Грузия), Комета х Эклер. Высоким содержанием сухих веществ отличаются: Дюна х Местный 625645 (Грузия), Гармония х Местный 626245 (Грузия). Как наиболее скороспелые характеризуются: Дюна х Майская, Осень х Местный 626245 (Грузия), Гармония х Местный 626245 (Грузия). Проведенными испытаниями доказана актуальность дальнейшего изучения в селекционном питомнике 8 выбранных гибридных комбинаций, выделенных по комплексу хозяйственно ценных признаков, для создания новых перспективных сортов дыни. Работа в этом направлении будет способствовать повышению объема и качества производимой продукции, содействовать дальнейшему развитию отрасли бахчеводства.
The work of the Bykovskaya melon selection experimental station includes, among other things, breeding melon varieties not inferior to zoned varieties in economically valuable traits, resistance to external environmental factors, and taste. Intersortual hybridization using repeated, stepwise crosses is the main direction of selection of the sourcematerialinmelonselection. The selection and analysis of the source material for crossing varieties with the individual ability to transmit to the offspring of valuable traits is an important breeding task. In order to expand the range of adapted productive melon varieties, the samples selected in collection nurseries that solve the breeding problem posed were used to obtain new hybrid melon combinations. In the nursery of the source material, 8 promising hybrid melon combinations were studied, which have an advantage in terms of valuable economic characteristics over the best zoned varieties. It has been established that the most fruitful are the samples: Dune x Local 625645 (Georgia), Harmony x Local 626245 (Georgia), Comet $x$ Eclair. High dry solids are distinguished by: Dune x Local 625645 (Georgia), Harmony x Local 626245 (Georgia). As the most precocious are characterized: Dune $x$ May, Autumn x Local 626245 (Georgia), Harmony x Local 626245 (Georgia). The tests proved the relevance of further study in the breeding nursery of 8 selected hybrid combinations, identified by a complex of economically valuable traits, to create new promising varieties of melon. Work in this direction will help to increase the volume and quality of products, contribute to the further development of the melon breeding industry. 
Ключевые слова: дыня, образец, вегетационный период, качество, сухое вещество, устойчивость, урожайность
Key words: melon, sample, vegetation period, quality, dry matter, resistance, yield
Введение. В РФ в устойчивом конкурентоспособном производстве сельскохозяйственной продукции решающую роль играют селекция и семеноводство сельскохозяйственных культур [1]. Условия современного рынка меняют приоритеты в селекции овощных культур. Приобретает актуальность создание нового генофонда, не уступающего западным селекционным разработкам [9]. Такая же задача стоит перед бахчеводами России.

На втором месте по популярности у производителей бахчевых культур стоит дыня. В Государственном реестре Российской Федерации допущено к использованию более 140 сортов и гибридов дыни. Однако обновление сортимента целесообразно, особенно если эти сорта обладают ценными хозяйственными и адаптивно значимыми признаками [2]. Кроме этого, возрастают требования к сортовому разнообразию дыни у производителей, что обусловлено освоением более северных регионов страны для возделывания этой культуры. Поэтому потребность в сортах раннего и среднего сроков созревания с высокими вкусовыми и пищевыми качествами плодов увеличивается [6].

При селекционной работе необходимо уделять должное внимание выведению сортов и гибридов, обладающих широкой экологической устойчивостью. Важным этапом селекционного процесса является создание модели сорта с учетом основных показателей, обеспечивающих его устойчивую урожайность и высокое качество продукции [11]. Для подбора образцов, которые соответствуют поставленной селекционной задаче, используют коллекционные питомники, в которых изучают разно- образные по географическому происхождению образцы с различными морфологическими и хозяйственно ценными признаками [3, 4]. При отборе исходного материала учитывают разнообразие по сочетанию хозяйственно важных признаков и соответствие цели селекции (модели сорта) [10].

Данная научно-исследовательская работа была выполнена с целью оценки и отбора исходного материала, полученного в результате гибридизации отобранных по комплексу хозяйственно ценных признаков образцов дыни.

Материалы и методы. Исследования проводили в питомнике исходного материала Быковской бахчевой селекционной опытной станции в 2016-2018 годах.

Особенностями климата зоны исследований являются резко выраженная континентальность и засушливость. На всей территории господствует антициклонный режим погоды. Наблюдается повышенная ветровая деятельность и частые пыльные бури. Суховейных дней до 40-60, а максимальная скорость ветра может достигать до 35 м/с [5]

Испытывали гибридные комбинации, полученные от скрещивания образцов, выделенных раннее из коллекционного питомника. Испытываемые образцы высевали по 30 штук на делянке. Площадь питания одного растения $2 \mathrm{~m}^{2}$. За стандарт был принят сорт дыни Осень.

В ходе проведения исследований выполняли: фенологические наблюдения по фазам роста и развития растений; морфологические исследования растений и плодов; учет заболеваний растений и плодов; селекционную оценку образцов; учет урожая путем взвешивания плодов на учетных делянках.
Исследования проводили в соответствии с «Методикой государственного испытания сельскохозяйственных культур» и методиками, разработанными для селекции овощных и бахчевых культур $[8,12]$

Результаты и обсуждение. В коллекционных питомниках Быковской бахчевой селекционной опытной станции раннее были отобраны образцы, имеющие преимущество по основным хозяйственно ценным признакам перед лучшими районированными сортами урожайность, содержание сухих веществ, яркая окраска плода, консистенция мякоти, устойчивость к био- и абиострессам.

Многочисленными исследования ми установлено, что содержание сухих веществ, консистенция мякоти, скороспелость у дыни наследуются промежуточно. Поэтому для получения сортов с хорошими вкусовыми качествами в скрещивание включали образцы, обладающие высоким содержанием сухих веществ. По вкусовым качествам из коллекции были выделены образцы: Местный 626245 (Грузия), Эклер. Яркой окраской фона плода отличался сорт Местный 625645 (Грузия). Наиболее скороспелыми были образцы: Таисия, Жансая. Сорта волгоградской селекции показали себя наиболее приспособленными к условиям возделывания в условиях Нижнего Поволжья.

Между выделенными по тем или иным признакам коллекционных образцами и наиболее перспективными сортами, выведенными Быковской бахчевой селекционной опытной станцией, провели гибридизацию.

В результате межсортовых скрещиваний были получены перспективные

Таблица 1 - Характеристика гибридных комбинаций в гибридном питомнике

(средние данные за 2016-2018 годы)

\begin{tabular}{|c|l|c|c|c|c|}
\hline $\begin{array}{c}\text { № } \\
\text { п/п }\end{array}$ & \multicolumn{1}{|c|}{$\begin{array}{c}\text { Наименование гибридной } \\
\text { популяции }\end{array}$} & $\begin{array}{c}\text { Длинна } \\
\text { вегетационного } \\
\text { периода, сут. }\end{array}$ & $\begin{array}{c}\text { Средняя масса } \\
\text { отобранных } \\
\text { плодов, кг }\end{array}$ & $\begin{array}{c}\text { Содержание } \\
\text { сухих веществ } \\
\text { в соке плода, \% }\end{array}$ & $\begin{array}{c}\text { Средняя } \\
\text { урожайность, } \\
\text { т/га }\end{array}$ \\
\hline 1. & Осень (стандарт) & 81 & 2,5 & $13,0-15,0$ & 14,2 \\
\hline 2. & Дюна х Местный 625645 (Грузия) & 70 & 4,2 & $14,5-17,0$ & 18,2 \\
\hline 3. & Осень х Местный 626245 (Грузия) & 72 & 4,5 & $15,0-15,5$ & 13,5 \\
\hline 4. & Гармония х Местный 626245 (Грузия) & 75 & 4,8 & $14,0-17,4$ & 15,2 \\
\hline 5. & Дюна х Зимовка & 80 & 3,0 & $12,0-15,4$ & 13,6 \\
\hline 6. & Комета х Эклер & 87 & 3,0 & $15,0-15,0$ & 15,0 \\
\hline 7. & Эклер х Осень & 82 & 2,4 & $13,8-15,0$ & 10,0 \\
\hline 8. & Таисия х Жансая & & 3,0 & $14,0-15,0$ & 10,1 \\
\hline НСР $_{05}$ & & & & 0,48 \\
\hline
\end{tabular}


гибридные комбинации: Дюна х Местный 625645 (Грузия), Осень х Местный 626245 (Грузия), Комета х Эклер, Эклер х Осень, Гармония х Местный 626245 (Грузия), Дюна х Зимовка, Таисия х Жансая. Характеристика этих образцов приведена в таблице 1 .

По скороспелости были выделены комбинации: Дюна х Местный 625645 (Грузия), Осень х Местный 626245 (Грузия), Гармония х Местный 626245 (Грузия). Длина вегетационного периода у этих комбинаций в период исследований была на 6-11 суток короче, чем у стандартного сорта Осень (81 сут.).

Высоким содержанием сухих веществ отличались комбинации Дюна х Местный 625645 (Грузия), Гармония х Местный 626245 (Грузия) - превышение значения этого показателя для данных комбинаций относительно его значения для стандартного сорта составило 2,0-2,4\%.

Наибольшей урожайностью характеризовались комбинации: Дюна х Местный 625645 (Грузия) - 18,2 т/га, Гармония х Местный 626245 (Грузия) - 15,2 т/га, Комета х Эклер - 15,0 т/га, стандарт Осень - 14,2 т/га.

Самую большую среднюю массу плода имели гибридные комбинации: Гармония х Местный 626245 (Грузия) - 4,8 кг, Осень х Местный 626245 (Грузия) - 4,5 кг, Дюна х Местный 625645 (Грузия) - 4,2 кг. Данные комбинации были проверены на устойчивость к антракнозу и мучнистой росе. Степень поражения этими заболеваниями оценивали по 5-балльной шкале (таблица 2).

Мучнистой росой меньше стандартного сорта Осень - 81,2\% были поражены гибридные комбинации Осень х Местный 626245 (Грузия) - 75,0\% и Гармония х Местный 626245 (Грузия) - 77,8\%. По баллу поражения на уровне стандарта поразилась комбинация Таисия х Жансая - 1,8 балла. Балл поражения других комбинаций превысил стандарт на 0,11,7 балла.
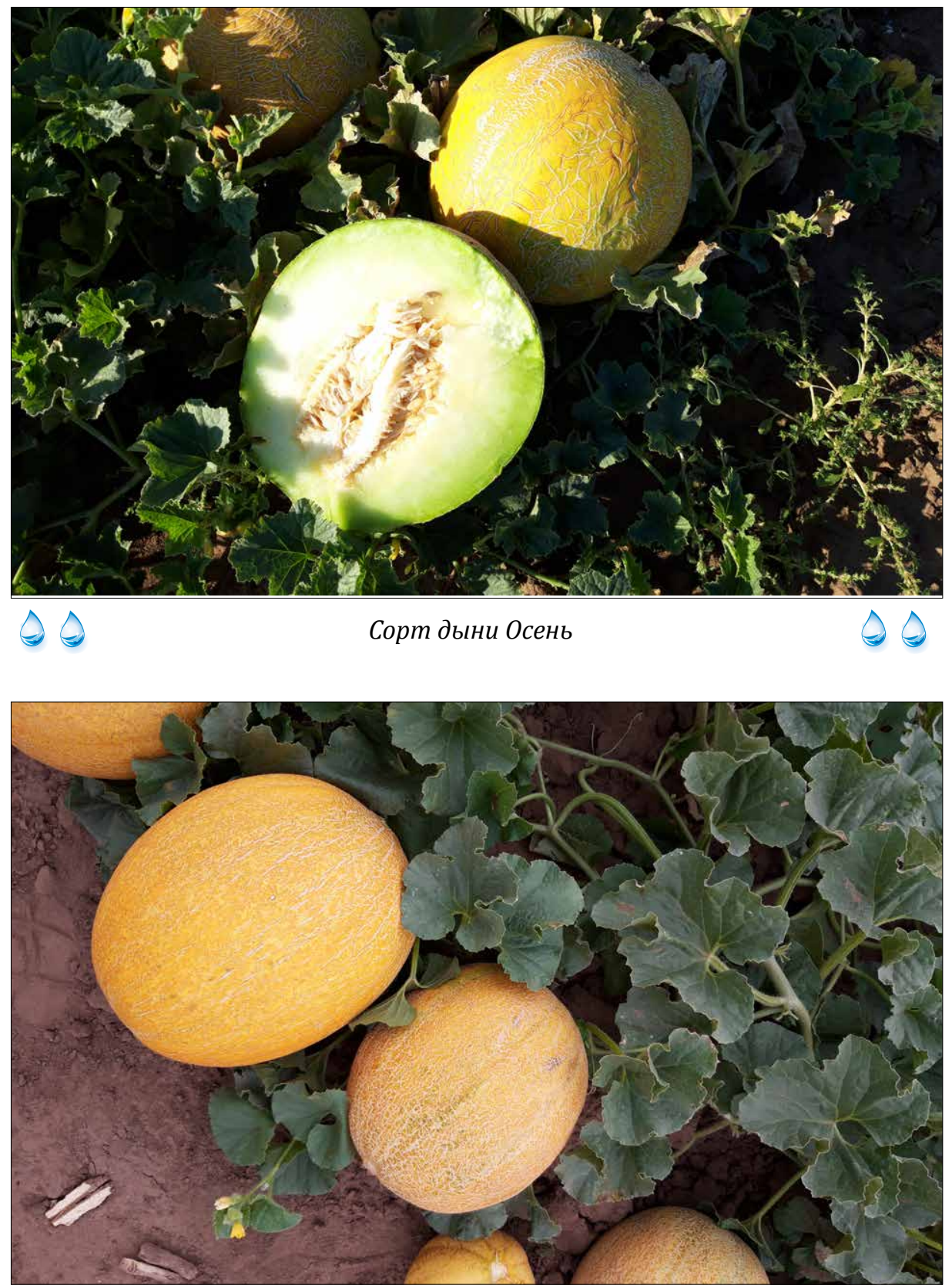

() Гибридная комбинация дыни Дюнах Местный 625645 (Грузия)

Таблица 2 - Устойчивость к антракнозу и мучнистой росе гибридных комбинаций дыни

\begin{tabular}{|c|c|c|c|c|c|}
\hline \multirow{2}{*}{$\begin{array}{c}\text { № } \\
\text { П/П }\end{array}$} & \multirow[b]{2}{*}{ Название образца } & \multicolumn{2}{|c|}{ Мучнистая роса } & \multicolumn{2}{|c|}{ Антракноз } \\
\hline & & $\begin{array}{c}\text { средний балл } \\
\text { поражения }\end{array}$ & $\begin{array}{c}\text { \% } \\
\text { поражения } \\
\end{array}$ & $\begin{array}{c}\text { средний балл } \\
\text { поражения }\end{array}$ & $\begin{array}{c}\% \\
\text { поражения } \\
\end{array}$ \\
\hline 1. & Осень (стандарт) & 1,8 & 81,2 & 2,3 & 100,0 \\
\hline 2. & Дюна х Местный 625645 (Грузия) & 2,9 & 88,8 & 2,0 & 100,0 \\
\hline 3. & Осень х Местный 626245 (Грузия) & 2,1 & 75,0 & 2,0 & 100,0 \\
\hline 4. & Гармония х Местный 626245 (Грузия) & 2,1 & 77,8 & 1,5 & 81,8 \\
\hline 5. & Дюна х Зимовка & 2,3 & 90,0 & 2,2 & 100,0 \\
\hline 6. & Комета х Эклер & 3,5 & 100,0 & 1,4 & 80,5 \\
\hline 7. & Эклер х Осень & 1,9 & 92,3 & 2,4 & 100,0 \\
\hline 8. & Таисия х Жансая & 1,8 & 91,4 & 3,8 & 100,0 \\
\hline
\end{tabular}


Наибольшую устойчивость к антракнозу проявили комбинации Гармония х Местный 626245 (Грузия) - 1,5 балла при $81,8 \%$ поражения и Комета х Эклер - 1,4 балла при 80,5\% поражения. Устойчивость стандартного сорта была оценена в 2,3 балла при 100\% поражения. Устойчивее стандарта к данному заболеванию были комбинации Дюна х Местный 625645 (Грузия) и Осень х Местный 626245 (Грузия), которые поразились на 2,0 балла при 100\% поражении.
Заключение. Получить новые сорта с заранее заданными параметрами: стабильная по годам урожайность, хорошие вкусовые качества плодов, дружность созревания, раннеспелость, устойчивость к болезням и стрессовым факторам внешней среды [7] можно при правильном подборе родительских пар.

Выведенные гибридные комбинации: Дюна х Местный 625645 (Грузия), Гармония х Местный 626245 (Грузия), Осень х Местный 626245 (Грузия), Комета х Эклер обладают комплексом перспективных хозяйственно ценных признаков. Эти гибридные комбинации будут использованы в селекционном процессе по созданию новых сортов дыни с высокой потенциальной урожайностью, хорошими вкусовыми качествами, устойчивостью к заболеваниям и стрессовым факторам среды.

\section{Библиографический список}

1. Берёзкин, А.А. Международный опыт развития селекции и семеноводства сельскохозяйственных культур: учебное пособие / А.А. Берёзкин, А.М. Малько, М.Ю. Чередниченко; РГАУ МСХА им. Тимирязева. - М.: РГАУ МСХА им. Тимирязева, 2012. - 447 с.

2. Быковский, Ю.А. Новые и перспективные сорта бахчевых культур / Ю.А. Быковский, Л.В. Емельянова, Т.М. Никулина // Картофель и овощи. - 2016. - №8. - С. 37-38.

3. Варивода, Е.А. Изучение исходного материала для селекции сортов и гибридов арбуза на засухоустойчивость и качество плодов / Е.А. Варивода, О.П. Варивода, Н.Г. Байбакова // Селекция на адаптивность и создание нового генофонда в современном овощеводстве (VI Квасниковские чтения): матер междунар. науч.-практич. конф., д. Верея, 8 августа 2013 г. / ВНИИО [и др.]. - М., 2013. - С. 96- 97.

4. Варивода, Е.А. Значение коллекционных питомников в селекционной работе / Е.А. Варивода, И.Н. Бочерова, М.С. Корнилова // Современное состояние проблемы и перспективы развития аграрной науки: матер. III междунар. науч. конф., г. Ялта, 24-28 сентября 2018 г. / НИИСХ Крыма [и др.]. - Ялта, 2018. - С. 115-116.

5. Варивода, Е.А. Результаты сортоиспытания новых сортов дыни в условиях Волгоградского Заволжья / Е.А. Варивода, М.С. Корнилова, Г.В. Варивода // Овощи России. - 2018. - №2. - С. 61-64.

6. Колебошина, Т.Г. Новые сорта арбуза, дыни и тыквы для товарного бахчеводства России, их конкурентноспособность в условиях рынка / Т.Г. Колебошина // Труды Кубанского государственного аграрного университета. - 2015. - №4. - С. 115-119.

7. Колебошина, Т.Г. Подбор родительских пар и создание исходного материала для селекции новых сортов арбуза / Т.Г. Колебошина, Г.С. Егорова, С.В. Малуева, Е.А. Варивода // Орошаемое земледелие. - 2018. - №4. - С. 44- 47.

8. Литвинов, С.С. Методика полевого опыта в овощеводстве / С.С. Литвинов. - М.: Россельхозакадемия, 2011. - 648 с.

9. Литвинов, С.С. Селекция и семеноводство - основа возрождения товарного овощеводства в России / С.С. Литвинов, Н.Н. Клименко, С.С. Арустамов // Картофель и овощи. - 2013. - №3. - C. 24.

10. Малуева, С.В. Коллекционные питомники, как основной материал для селекционной работы в бахчеводстве / С.В. Малуева, Л.В. Емельянова, Т.М. Никулина // Научное обеспечение отрасли овощеводства России в современных условиях: матер междунар. науч.-практич. конф., Москва, 1-4 ноября 2015 г. / ВНИИО [и др.]. - М., 2015. - С. 308.

11. Солдатенко, А.В. Экологические аспекты регулирования накопления радионуклидов овощными растениями / А.В. Солдатенко. - М.: ФГБНУ ФНЦО, 2019. - 344 с.

12. Фурса, Т.Б. Селекция бахчевых культур: методические указания / Т.Б. Фурса; ВИР. - Л.: ВИР, 1988. - 68 с.

Дополнительные сведения об авторах:

Мария Сергеевна Корнилова, младший научный сотрудник отдела селекции, bbsos34@yandex.ru,

Елена Александровна Варивода, старший научный сотрудник отдела селекции, bbsos34@yandex.ru

\section{Bibliographic list}

1. Berezkin, A.A. International experience in the development of selection and seed production of agricultural crops / A.A. Berezkin, A.M. Malko, M.Yu. Cherednichenko; RGAU MAA them. Timiryazev. M.: RGAU MAA them. Timiryazev, 2012. - P. 447.

2. Bykovskij, Yu.A. New and promising varieties of gourds / Yu.A. Bykovskij, L.V. Emel'yanova, T.M. Nikulina // Potatoes and vegetables. - 2016. - No.8. - P. 37-38.

3. Varivoda, E.A. The study of the source material for the selection of varieties and hybrids of watermelon for drought tolerance and fruit quality / E.A. Varivoda, O.P. Varivoda, N.G. Bajbakova // Selection for adaptability and the creation of a new gene pool in modern vegetable growing (VI Kvasnikov readings): Mater. Int scientific and practical Conf., Vereya village, August 8, 2013 / VNIIO [et al.]. - M., 2013. - P. 96-97.

4.Varivoda, E.A. The value of collection nurseries in breeding work / E.A. Varivoda, I.N. Bocherova, M.S. Kornilova // The current state of the problem and prospects for the development of agricultural science: Mater. III international scientific Conf., Yalta, September 24-28, 2018 / Research Institute of Crimea [et al.]. - Yalta, 2018. - P $115-116$.

5. Varivoda, E.A. The results of variety testing of new varieties of melon in the Volgograd Trans-Volga region / E.A. Varivoda, M.S. Kornilova, G.V. Varivoda // Vegetables of Russia. - 2018. - No.2. - P. 61- 64 .

6. Koleboshina, T.G. Selection of parental pairs and creation of source material for breeding new varieties of watermelon / T.G. Koleboshina // Proceedings of the Kuban State Agrarian University. - 2015. - No.4. - P. 115-119.

7. Koleboshina, T.G. Selection of parental pairs and creation of source material for breeding new varieties of watermelon / T.G. Koleboshina, G.S. Egorova, S.V. Malueva, E.A. Varivoda // Irrigated agriculture. - 2018. - No.4. - P. 44-47.

8. Litvinov, S.S. Methods of field experience in vegetable growing / S.S. Litvinov. - M.: Russian Agricultural Academy, 2011. - 648 p.

9. Litvinov, S.S. Breeding and seed growing - the basis of the revival of commodity vegetable growing in Russia / S.S. Litvinov, N.N. Klimenko, S.S. Arustamov // Potatoes and vegetables. - 2013. - №3. - P. 24.

10. Malueva, S.V. Collection nurseries as the main material for selective work in melon growing / S.V. Malueva, L.V. Emelyanova, T.M. Nikulina // Scientific support of the Russian vegetable industry in modern conditions: Mater. Int. scientific and practical Conf., Moscow, November 1-4, 2015 / VNIIO [et al.]. - M., 2015. - P. 308.

11. Soldatenko, A.V. Environmental aspects of regulation of the accumulation of radionuclides by vegetable plants / A.V. Soldatenko. - M.: FGBNU FNCO, 2019. - 344 p.

12. Fursa, T.B. Selection of gourds: guidelines / T.B. Fursa; VIR. L.: VIR, 1988. - 68 p.

\section{Additional information about the authors:}

Mariya Sergeevna Kornilova, junior researcher bykovsky melon selective, bbsos34@yandex.ru,

Elena Aleksandrovna Varivoda, senior researcher bykovsky melon selective, bbsos34@yandex.ru 